\title{
Correction for Series Resistance in A.G. Polarography
}

\author{
by \\ Sudarshan LAL and H.H. BAUER \\ Department of Chemistry, University of Kentucky, Lexington, Kentucky 40506
}

(Received Oct. 16, 1970)

\begin{abstract}
The apparent or measured series resistance of an electrochemical cell is influenced by the geometry of the electrodes. At a dropping mercury electrode, the resistance increases as the frequency of the measuring signal decreases. The question arises as to! how to correct for the series resistance when calculations are made of faradaic impedance. It is shown here that the use of the high-frequency limit of the resistance gives better results than use of the apparent resistance at each frequency. Nevertheless, the correction made in this way represents only an approximation.
\end{abstract}

Calculations of the faradaic impedance of redox processes are based on an equivalent electrical circuit of the electrochemical cell as shown in Figure 1. The validity of the calculations depends on the use of correct values for the double-layer capacity and the series resistance. These quantities are obtained from measurements carried out so as to minimize the effect of the faradaic impedance (absence of depolarizer or some type of extrapolation procedure).

With conventional, blunt-tipped, capillaries, measurements made at dropping mercury electrodes in the absence of depolarizer show a pronounced variation of the apparent series resistance with changing frequency of the alternating signal: the resistance increases as the frequency decreases. Newman ${ }^{1)}$ has shown that such an effect can be produced by shielding of the drop by the capillary. The extent of the frequency dispersion of the resistance depends on the relative magnitudes of the double-layer capacity and the series resistance; or, more generally (in the presence of a depolarizer), on the relative magnitudes of the interfacial impedance and the series resistance. Therefore, in the frequency range where dispersion is observed, the series resistance in absence of depolarizer will differ from that in the presence of depolarizer; proper correction must take into account this factor.

In this note, it is shown that the use of the high-frequency limit of the measured resistance is a better approximation than use of the apparent resistance at a given frequency measured in absence of depolarizer.

\section{Experimental}

Two systems have been examined: one where charge transfer is comparatively fast $\left(\mathrm{Cd}(\mathrm{II}) / \mathrm{Cd}(\mathrm{Hg})\right.$ in $\left.1 \mathrm{KNO}_{3}\right)$, and one where the process is of moderate speed $(\mathrm{Zn}$ 
(II) $/ \mathrm{Zn}(\mathrm{Hg})$ in $\left.1 M \mathrm{NaClO}_{4}\right)$.

Reagent-grade chemicals were used

in all cases. The cadmium system was studied with a Princeton Applied Research Corporation Electrochemistry System 170; the zinc system was studied by means of manual apparatus described in detail elsewhere ${ }^{2)}$.

Experiments were carried out at $25^{\circ} \mathrm{C}$. All potentials were measured vs. S.C.E.

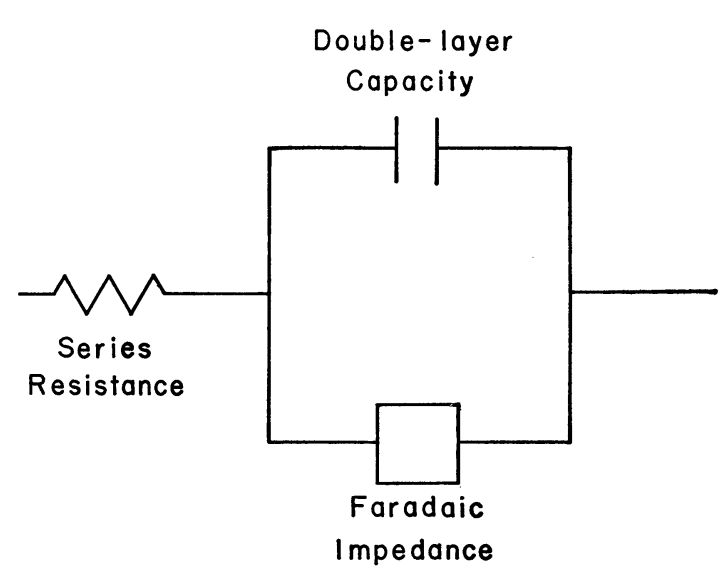

Results

Table I reports results of measurements at a d.m.e. in $1 M \mathrm{KNO}_{3}$, obtained with the P.A.R. instrument which is limited to a frequency range of up to $1 \mathrm{kHz}$. The double-layer capacity is constant, but the series resistance increases at lower frequencies as would be expected at a shielded drop according to the treatment of Newman ${ }^{1}$. Table II shows the results of calculations made for the system $\mathrm{Cd}(\mathrm{II}) / \mathrm{Cd}(\mathrm{Hg})$ in $1 \mathrm{M}$ $\mathrm{KNO}_{3}$, on two bases: using the actual measured series resistance at each frequency, and using the high-frequency $(1 \mathrm{kHz})$ magnitude of the resistance for calculations at all frequencies. It is evident that calculations based on the high-frequency resistance yield results that satisfy a simple diffusion-controlled model ( Randles $^{3)}$ ), whereas calculations based on the "actual" values of the resistance (measured in absence of depolarizer) at various frequencies result in scattered values, including negative values for the charge-transfer resistance.

Similar results and conclusions emerge from measurements on $1 M \mathrm{NaClO}_{4}$, in presence and absence of $\mathrm{Zn}(\mathrm{II})$ : Table III shows results obtained in the supporting electrolyte, Table IV those obtained in the presence of $\mathrm{Zn}(\mathrm{II})$. It is apparent that the use of "actual" as opposed to "high-frequency" resistance values leads to more serious errors, the smaller is the charge-transfer resistance of the system. This is obvious even on a priori grounds-any error in series-resistance magnitude is relatively

Table I D.M.E., $1 M \mathrm{KNO}_{3},-0.58 \mathrm{~V}$ vs. S.G.E.

\begin{tabular}{c|c|c}
\hline Frequency & Double-Layer Capacity & Series \\
\hline $26 \mathrm{~Hz}$ & $0.471 \mu \mathrm{f}$ & $735 \Omega$ \\
46 & 0.481 & 384 \\
73 & 0.466 & 271 \\
137 & 0.461 & 174 \\
275 & 0.462 & 140 \\
562 & 0.466 & 122 \\
1008 & 0.485 & 101.5 \\
\hline
\end{tabular}


Table II D.M.E., $1 M \mathrm{KNO}_{3}$ plus Cd(II), -0.58V vs. S.C.E.

\begin{tabular}{|c|c|c|c|c|c|c|}
\hline \multirow{2}{*}{ Frequency } & \multicolumn{3}{|c|}{$\begin{array}{l}\text { Calculations using Resistance } \\
\text { Values from Table I }\end{array}$} & \multicolumn{3}{|c|}{$\begin{array}{l}\text { Calculations using Resistance } \\
\text { Value of } 101.5 \mathrm{ohms}\end{array}$} \\
\hline & \begin{tabular}{|} 
In-Phase \\
Faradaic \\
Impedance \\
$\quad$ (i)
\end{tabular} & $\begin{array}{l}\text { Out-of-Phase } \\
\text { Faradaic } \\
\text { Impedance } \\
\quad \text { (ii) }\end{array}$ & $\begin{array}{c}\text { Charge-Transfer } \\
\text { Resistance } \\
\text { (i)-(ii) }\end{array}$ & \begin{tabular}{|l} 
In-Phase \\
Faradaic \\
Impedance \\
$\quad$ (iii)
\end{tabular} & $\begin{array}{l}\text { Out-of-Phase } \\
\text { Faradaic } \\
\text { Impedance } \\
\quad \text { (iv) }\end{array}$ & $\begin{array}{l}\text { Charge-Transfer } \\
\text { Resistance } \\
\text { (iii)-(iv) }\end{array}$ \\
\hline \multicolumn{7}{|c|}{$5 \times 10^{-5} M \mathrm{Cd}(\mathrm{II})$} \\
\hline $26 \mathrm{~Hz}$ & $6720 \Omega$ & $8670 \Omega$ & $-1950 \Omega$ & $8170 \Omega$ & $7490 \Omega$ & $680 \Omega$ \\
\hline 46 & 5230 & 6190 & -960 & 5960 & 5420 & 540 \\
\hline 73 & 4410 & 4900 & -490 & 4900 & 4230 & 670 \\
\hline 137 & 3550 & 3600 & -50 & 4060 & 3340 & 720 \\
\hline 275 & 2580 & 2480 & 100 & 2710 & 2010 & 700 \\
\hline 562 & 1640 & 1910 & -270 & 1770 & 1460 & 310 \\
\hline \multirow[t]{2}{*}{1008} & 454 & 3340 & -2890 & 454 & 3340 & -2890 \\
\hline & & & & \multicolumn{3}{|c|}{ Average, 26 to $275 \mathrm{~Hz}: 662 \Omega$} \\
\hline \multicolumn{7}{|c|}{$10^{-4} M \mathrm{Cd}(\mathrm{II})$} \\
\hline 26 & 3030 & 4060 & -1030 & 4050 & 3650 & 400 \\
\hline 46 & 2490 & 2990 & -500 & 3000 & 2690 & 310 \\
\hline 73 & 2130 & 2400 & -270 & 2470 & 2150 & 320 \\
\hline 137 & 1710 & 1700 & 10 & 1870 & 1530 & 340 \\
\hline 275 & 1250 & 1230 & 20 & 1360 & 1070 & 290 \\
\hline 562 & 827 & 913 & -86 & 903 & 771 & 132 \\
\hline \multirow[t]{2}{*}{1008} & 667 & 1130 & -462 & 667 & 1130 & -463 \\
\hline & & & & \multicolumn{3}{|c|}{ Average, 26 to $275 \mathrm{~Hz}: 332 \Omega$} \\
\hline
\end{tabular}

Table III D.M.E., $1 M \mathrm{NaClO}_{4}$

\begin{tabular}{c|c|c|c|c}
\hline \multirow{2}{*}{ Frequency } & \multicolumn{2}{|c|}{$-0.92 \mathrm{~V}$ vs. S.G.E. } & \multicolumn{2}{c}{$-0.94 \mathrm{~V}$ vs. S.G.E. } \\
\cline { 2 - 5 } & $\begin{array}{c}\text { Double-Layer } \\
\text { Capacity }\end{array}$ & Series Resistance & $\begin{array}{c}\text { Double-Layer } \\
\text { Capacity }\end{array}$ & Series Resistance \\
\hline $26 \mathrm{~Hz}$ & $.532 \mu \mathrm{F}$ & 313 & $.527 \mu \mathrm{F}$ & 355 \\
46 & .534 & 172 & .533 & 204 \\
71 & .543 & 132 & .539 & 155 \\
143 & .548 & 116 & .537 & 115 \\
283 & .546 & 89 & .537 & 94 \\
567 & .544 & 85 & .529 & 85 \\
1114 & .543 & 81 & .532 & 80 \\
1424 & .540 & 78 & .531 & 79 \\
1813 & .541 & 78 & .531 & 78 \\
2020 & .544 & 77 & .535 & 79 \\
2531 & .545 & 77.5 & .538 & 77 \\
3051 & .533 & 78 & .539 & 78 \\
4044 & .530 & 77 & .529 & 77 \\
5058 & .521 & 76 & .516 & 77 \\
10454 & .512 & 75 & .506 & 76 \\
20768 & .518 & 75.5 & .515 & 76 \\
31266 & .492 & 75 & .492 & 75 \\
\hline
\end{tabular}


Table 4 D.M.E., $1 M \mathrm{NaClO}_{4}$ plus $\mathrm{Zn}(\mathrm{II})$

\begin{tabular}{|c|c|c|c|c|c|c|}
\hline \multirow{2}{*}{ Frequency } & \multicolumn{3}{|c|}{$\begin{array}{l}\text { Calculations using Resistance } \\
\text { Values from Table III }\end{array}$} & \multicolumn{3}{|c|}{$\begin{array}{l}\text { Calculations using Resistance } \\
\text { Value of } 76.5 \mathrm{ohms}\end{array}$} \\
\hline & $\begin{array}{l}\text { In-Phase } \\
\text { Faradaic } \\
\text { Impedance } \\
\quad \text { (i) }\end{array}$ & $\begin{array}{l}\text { Out-of-Phase } \\
\text { Faradaic } \\
\text { Impedance } \\
\quad \text { (ii) }\end{array}$ & \begin{tabular}{|} 
Charge-Transfer \\
Resistance \\
(i)-(ii)
\end{tabular} & $\begin{array}{l}\text { In-Phase } \\
\text { Faradaic } \\
\text { Impedance } \\
\quad \text { (iii) }\end{array}$ & $\begin{array}{l}\text { Out-of-Phase } \\
\text { Faradaic } \\
\text { Impedance } \\
\quad \text { (iv) }\end{array}$ & $\begin{array}{l}\text { Charge-Transfer } \\
\text { Resistance } \\
\text { (iii)-(iv) }\end{array}$ \\
\hline \multicolumn{7}{|c|}{$2 \times 10^{-4} M \mathrm{Zn}(\mathrm{II}) ;-0.94 \mathrm{~V}$ vs. S.G.E. } \\
\hline $26 \mathrm{H} \iota$ & $10600 \Omega$ & $4560 \Omega$ & $6040 \Omega$ & 10900 & 3850 & $7050 \Omega$ \\
\hline 46 & 9660 & 3620 & 6040 & 9670 & 3040 & 6630 \\
\hline 71 & 9100 & 2910 & 6190 & 8950 & 2370 & 6580 \\
\hline 143 & 8160 & 2550 & 5610 & 7740 & 1900 & 5840 \\
\hline 283 & 7490 & 2350 & 5140 & 6830 & 1660 & 5170 \\
\hline 567 & 6750 & 2710 & 4040 & 5780 & 1650 & 4130 \\
\hline 1114 & 5320 & 2640 & 2680 & 4370 & 1490 & 2880 \\
\hline 1424 & 4830 & 4010 & 820 & 4160 & 2130 & 2030 \\
\hline 1813 & 4210 & 2280 & 1930 & 3340 & 1170 & 2170 \\
\hline 2020 & 4470 & 2730 & 1740 & 3270 & 1100 & 2170 \\
\hline \multicolumn{7}{|c|}{$10^{-3} M \mathrm{Zn}(\mathrm{II}) ;-0.92 \mathrm{~V}$ vs. S.G.E. } \\
\hline $46 \mathrm{~Hz}$ & 9670 & 9210 & 460 & 9980 & 8520 & 1460 \\
\hline 71 & 8960 & 9240 & -280 & 9240 & 7760 & 1480 \\
\hline 143 & 7140 & 7040 & 100 & 7340 & 5840 & 1500 \\
\hline 283 & 5730 & 4900 & 830 & 5770 & 4260 & 1510 \\
\hline 567 & 4300 & 4060 & 240 & 4230 & 2960 & 1170 \\
\hline 1114 & 2010 & 1770 & 240 & 2730 & 1330 & 1400 \\
\hline 1424 & 2010 & 905 & 1105 & 1920 & 764 & 1160 \\
\hline 1813 & 1690 & 559 & 1130 & 1550 & 419 & 1130 \\
\hline 2020 & 1500 & 482 & 1020 & 1440 & 418 & 1020 \\
\hline
\end{tabular}

more important when the charge-transfer process is rapid (charge-transfer resistance small).

Some experiments were carried out with "pencil -sharpened"capillaries: the blunt end of the capillary was carefully ground away. No measurable difference in frequency dispersion could be detected, indicating that the shielding effect is due primarily to the glass immediately adjacent to the top of the drop. Siliconizing the capillary also had no effect on the frequency dispersion, indicating that the latter was indeed a result of shielding and not of a solution film inside the capillary.

\section{Conclusions}

1. At blunt-tipped capillaries, the frequency dispersion of series resistance (pronounced at low frequencies) and double-layer capacity (small or negligible) follows, at least qualitatively, the calculations (1) for a spherical electrode tangent to an insulating plane.

2. In calculations of charge-transfer-resistance values, the high-frequency limit of the series resistance should be used.

Consequently, 
3. Instruments used for impedance studies of redox processes should permit measurements over a sufficiently large range of frequencies that the high-frequency limit of the series resistance can be obtained.

Finally, it is evident that the reliability of impedance measurements of electrochemical processes becomes greater if electrodes can be used where a uniform distribution of current prevails across the surface of the working electrode. Then, measurements will not be complicated by frequency dispersion resulting from purely geometric factors.

\section{Acknowledgement}

This work was carried out under a Project Themis contract (DAAB07-69-C-0366) from the Department of Defense.

\section{References}

1) J. Newman, J Electrochem. Soc., 117, ,198 (1970).

2) D. Britz and H.H. Bauer, J. Sci.Instrum., 44, 843 (1968).

3) J.E.B. Randles, Faraday Soc. Disc., 1, 11 (1947). 